\title{
Perbedaan Pengaruh Pemberian Infus HES Dengan Berat Molekul 40 kD dan 200 kD Terhadap Plasma Prothrombin Time dan Partial Thromboplastin Time Kajian Pada Pasien Dengan Perdarahan Sampai $20 \%$ Estimated Blood Volume
}

Hari Hendriarto Satoto*, Ery Leksana*, Uripno Budiono*

*Bagian Anestesiologi dan Terapi Intensif FK Undip/ RSUP Dr. Kariadi, Semarang

\section{ABSTRACT}

Background : There were increased number of patient with major surgey. High molecular weight HES had better haemodynamic function but affected coagulation much. PT and PTT study were done to know effect HES in coagulation system.

Objective : To compare difference of PT and PTT between HES $40 \mathrm{kD}$ and HES $200 \mathrm{kD}$ in patient up to $20 \%$ Estimated Blood Volume bleeding.

Methods : We had experimental study with "Single Blind Randomized Clinical Trial" design. 46 patients were randomly divide into 2 group. Group 1 were given HES $40 \mathrm{kD}$ and group 2 were given HES $200 \mathrm{kD}$. All the patient were administrated PT and PTT study before operation. In operating room, they were inducted by thiopentone $5 \mathrm{mg} / \mathrm{kgBB}$, atracurium besilat $0,5 \mathrm{mg} / \mathrm{kgBB}$, inhalation agent with isofluran, tramadol atracurium were added in necessary. PT and PTT were administrated 15 minute and 2 hours after administrated. Statisic data were analyzed with SPSS 11,5 for windows.

Result : It was demonstrated in this study that HES $00 \mathrm{kD}$ had longer PTT from preoperation $(29,72 \pm 1,70)$ to $(32,69 \pm 0,77)$ and preoperation $P T(12,85 \pm 0,86)$ to $(13,31 \pm 0,73)$. There were longer PTT in HES $40 \mathrm{kD}$ from $(29,89 \pm 1,47)$ to $(34,10 \pm$ 1,30). There were significantly higher PTT in HES $200 \mathrm{kD}$ after administration of HES. (mean 4,21 $\pm 1,28$ vs 2,97 $\pm 1,76$ repectively, $p=0,009 ; p<0,05$ ).

Conclusion : HES $200 \mathrm{kD}$ was significantly longer PT and PTT than HES $40 \mathrm{kD}$.

Key words : HES, Prothrombin Time, Partial Thromboplastin Time.

\section{ABSTRAK}

Latar belakang : Pasien dengan operasi besar yang beresiko terjadi perdarahan semakin meningkat setiap tahun. HES dengan berat molekul besar mempertahankan hemodinamik lebih baik tetapi mengganggu faktor koagulasi. Pemeriksaan PT dan PTT dilakukan untuk memeriksa pengaruh HES pada koagulasi.

Tujuan : Membuktikan pemanjangan PT dan PTT pada pemberian larutan HES $40 \mathrm{kD}$ dan HES $200 \mathrm{kD}$ terhadap pasien yang menjalani operasi dengan pendarahan sampai $20 \% \mathrm{EBV}$.

Metode : Dilakukan penelitian eksperimental pada 46 pasien dengna desain "Single Blind Randomized Clinical Trial". Kelompok penelitian dibagi menjadi 2 kelompok secara acak, masing-masing 23 pasien. Pasien diambil sampel PT dan PTT pre operasi. Pasien diinduksi dengan thiopentone $5 \mathrm{mg} / \mathrm{kgBB}$, atracurium besilat $0,5 \mathrm{mg} / \mathrm{kgBB}$, pemeliharaan anestesi dengan isofluran, tramadol sebagai analgetik dan ditambahakan atracurium bila perlu. Sebagai cairan rumatan anestesi, kelompok I (HES $40 \mathrm{kD}$ ) dan kelompok II (HES $200 \mathrm{kD})$ sebagai pengganti kehilangan darah. 15 menit dan 4 jam setelah pemberian perlakuan dilakukan pemeriksaan PT dan PTT. Analisis data statistik menggunakan SPSS 11,5 for windows. 
Hasil : Dari hasil penelitian, pemberian ES 200 kD memperpanjang PTT dari preoperasi $(29,72 \pm 1,70)$ menjadi $(32,69 \pm 0,77)$ dan PT dari preoperasi $(12,85 \pm 0,86)$ menjadi (13,31 \pm 0,73). Pada HES $40 \mathrm{kD}$ didapatkan pemanjangan PTT dari preoperasi $(29,89 \pm$ 1,47) menjadi $(34,10 \pm 1,30)$. Analisis statistik antara PTT kelompok HES $40 \mathrm{kD}$ dan 200 $k D$ menunjukkan hasil berbeda bermakna dengan nilai $p=0.009(p<0.05)$.

Simpulan : Pemberian HES 200 kD memperpanjang PT dan PTT lebih besar dari pada HES $40 \mathrm{kD}$.

Kata kunci : HES, Prothrombin Time, Partial Thromboplastin Time.

\section{PENDAHULUAN}

Pasien yang mengalami pembedahan semakin meningkat dari tahun ke tahun. Pada tahun 2006 di RSUP Dr.Kariadi terdapat 6499 pasien yang mengalami pembedahan dengan 4390 pasien $(67,5 \%)$ dilakukan operasi dalam kategori mayor. ${ }^{1}$ Operasi mayor adalah operasi besar dengan kemungkinan perdarahan lebih dari $20 \%$ estimated blood volume (EBV) yang akan berpotensi terjadi syok. ${ }^{2,3}$ Kehilangan darah dapat diganti dengna kristaloid, koloid atau darah. ${ }^{4}$ Koloid mempunyai keuntungan yaitu efek intravaskular lama, reaksi imunologi minimal, infeksi virus, parasit, bakteri minimal dan tidak didapatkan keracunan sitrat sebagai antikoagulan darah. Kerugian koloid yaitu reaksi anafilaksis, edema paru, penurunan filtrasi ginjal dan gangguan koagulopati. ${ }^{5,6,7}$

Terdapat beberapa jenis koloid yaitu hydroxy ethyl starch (HES), dextran, albumin dan gelatin. HES merupakan koloid sintetis yang paling sering digunakan. HES mempunyai keuntungan yaitu harga lebih murah dibanding albumin dan reaksi anafilaksis lebih kecil dibandingkan dengan koloid lain. ${ }^{7}$ HES mempertahankan tekanan osmotik koloid plasma, meminimalkan akumulasi cairan interstitial lebih baik dan mempunyai waktu paruh lebih panjang sehingga bertahan lebih lama di darah dibandingkan dengan kristaloid. Pemberian HES sebagai cairan substitusi diberikan sesuai perdarahan yang keluar, dibanding dengan kristaloid yang memerlukan volume yang lebih besar, yaitu diberikan 3 kali perdarahan yang terjadi. ${ }^{8,9}$ HES dengan berat molekul besar mempunyai keuntungan yaitu memperbaiki keadaan hemodinamik lebih baik tetapi mempunyai kerugian yaitu gangguan faktor koagulasi lebih besar dan kerja ginjal lebih berat. ${ }^{10}$

Pemeriksaan Protrombin Time (PT) digunakan untuk memeriksa pembekuan darah melalui jalur ekstrinsik dan jalur bersama yaitu faktor pembekuan VII, X, $\mathrm{V}$, protrombin dan fibrinogen. Prothrombine time adalah waktu yang diperlukan untuk terbentuknya bekuan bila pada plasma sitrat ditambahakan thromboplastin jaringan. Pemeriksaan Partial Thromboplastin Time (PTT) digunakan untuk menguji pembekuan darah melalui jalur intrinsik dan jalur bersama yaitu faktor pembekuan XII, prekalikrein, kininogen, XI, IX, VIII, X, $\mathrm{V}$, protrombin dan fibrinogen. Partial thromboplastin adalah campuran fosfolipid yang merupakan pengganti platelet factor 3 (PF3) dalam sistem reaksi APTT. Bila campuran plasma sitrat dan partial thromboplastin ditambah dengan larutan yang mengandung ion calsium, maka terjadi pembekuan. ${ }^{11,12,13,14,15}$

Dari penelitian yang dilakukan KozekLangenecker dan Arellano menyatakan bahwa HES menurunkan faktor VIII dan faktor von Willebrand. Dimana hal ini 
akan menyebabkan penurunan fungsi koagulasi terutama faktor intrinsik. ${ }^{16,17,18}$ Sedangkan Madjpur melaporkan pemerian HES dengan berat molekul tinggi menurunkan fungsi koagulasi (faktor ekstrinsik dan intrinsik) dan memperpanjang waktu paruh dalam darah. ${ }^{19}$ Dari penelitian-penelitian tersebut didapatkan masih ada perbedaan titik tangkap atau mekanisme pengaruh HES terhadap fungsi koagulasi. Pengaruh HES terhadap fungsi koagulasi yang terbanyak disebut di literatur adalah faktor VIII dan faktor von Willebrand yang merupakan faktor intrinsik, namun ada juga yang mengemukakan pengaruh terhadap faktor ekstrinsik.

Tujuan penelitian ini adalah untuk membuktikan pemanjangan PT dan PTT pada pemberian larutan HES $40 \mathrm{kD}$ dan HES $200 \mathrm{kD}$ terhadap pasien yang menjalani operasi dengan pendarahan sampai $20 \%$ EBV. Hasil penelitian ini diharapkan dapat sebagai acuan dalam pemilihan larutan koloid pada operasi yang memiliki tendensi terjadinya perdarahan durante dan pasca operasi. Penelitian ini meneliti hal baru dimana dari penelitian sebelumnya belum pernah dibandingkan nilai PT dan PTT antara HES $40 \mathrm{kD}$ dan $200 \mathrm{kD}$, pada penelitian ini ditambahkan analisa mengenai perubahan nilai PT dan PTT.

\section{METODE}

Penelitian dikerjakan pada tanggal 14-28 November 2008 dan telah disetujui oleh Ketua Bagian Anestesi Fakultas Kedokteran Univesitas Diponegoro/ RSUP Dr.Kariadi Semarang. Penelitian ini juga sudah memperoleh ijin dari Komisi Etik \& Penelitian FK UNDIP/RSUP Dr.Kariadi serta dekan FK UNDIP dan Direktur RSUP Dr.Kariadi. jam sebelum operasi, kebutuhan cairan selama operasi dipenuhi sebelum operasi dengan menggunakan RL sebelum
Setiap pasien yang dilakukan penelitian telah dimintakan persetujuan. Jenis penelitian adalah Single Blind Randomized Clinical Trial dengan metode randomisasi dengan tabel random. Sampel penelitian adalah pasien operasi elektif di Instalasi Bedah Sentral RSUP Dr. Kariadi Semarang yang memenuhi kriteria inklusi dan eksklusi.

Kriteria inklusi antara lain adalah usia 1645 tahun, status fisik ASA I-II, menjalani operasi dengan anestesi umum, lama operasi 1-3 jam, pasien dengan perdarahan 10-20\% estimated blood volume (EBV), berat badan normal, dan bersedia ikut dalam penelitian. Sedangkan kriteria eksklusi antara lain pasien dengan kontraindikasi pemakaian obat anestesi yang digunakan yaitu isofluran, thiopental, atracurium besilat dan tramadol, pasien yang mengkonsumsi obat-obatan antikoagulan, pasien dengan kadar trombosit < 100.000/ $\mu \mathrm{L}$, pasien dengan kadar SGOT > $50 \mathrm{I} / \mathrm{U}$ dan SGPT $>100 \mathrm{IU}$, pasien yang mendapat pemberian transfusi darah selama perlakuan, pasien dengan penyakit perdarahan dan pasien dengan kehamilan.

Seleksi penderita dilakukan saat kunjungan prabedah di RSUP Dr.Kariadi Semarang pada penderita yang akan menjalani operasi elektif dengan anestesi umum, bedasarkan kriteria yang telah ditetapkan sebelumnya. Penderita diberikan penjelasan tentang hal-hal yang akan dilakukan, serta bersedia untuk mengikuti penelitian dan mengisi informed consent. Pasien secara random dibagi menjadi 2 kelompok yaitu kelompok I : larutah HES 40kD, kelompok II : larutan HES 200 kD. Sehingga masing-masing kelompok berjumlah 23.Semua pasien dipuasakan 6 induksi. Sampel diambil dari akses jalur pembuluh darah vena perifer sebanyak 3cc. 
Sampel dimasukkan tabung vakum plastik yang sudah berisi citrate anticoagulant. Sampel segera dikirim ke Laboratorium Patologi Klinik RSUP Dr.Kariadi sebagai sampel sebelum perlakuan untuk dilakukan pemeriksaan PT dan PTTK.

Saat operasi semua pasien diinduksi dengna thiopentone $5 \mathrm{mk} / \mathrm{kgBB}$, setelah reflek bulu mata hilang diberikan atracurium besilat $0,5 \mathrm{mg} / \mathrm{kgBB}$, kemudian dilakukan intubasi endotrakheal dan dilanjutkan penggunaan isoflurane sebagai agen anestesi. Untuk cairan rumatan anestesi pada kedua kelompok mendapat perlakuan berbeda, kelompok I menggunakan larutan HES $40 \mathrm{kD}$ sebagai pengganti kehilangan darah sampai dengan operasi berakhir, sedangkan kelompok II menggunakan larutan HES $200 \mathrm{kD}$ sebagai pengganti kehilangan darah sampai dengan operasi berakhir.

Kedua kelompok dapat diberikan penambahan obat pelumpuh otot atracurium besilat $0,2 \mathrm{mg} / \mathrm{kgBB}$ bila diperlukan dan pemeberian tramadol sebagai analgetik intravena rumatan. Kurang lebih 15 menit setelah pemberian larutan HES, sampel darah pada kedua kelompok perlakuan diambil sebanyak 3 cc, dimasukkan tabung vacum plastik yang sudah berisi citrate anticoagulant. Sampel segera dikirim ke Laboratorium Patologi Klinik RSUP Dr.Kriadi sebagai sampel sesudah perlakuan untuk dilakukan pemeriksaan Plasma Prothrombin Time (PT) dan Partial Thromboplastin Time (PTT). 4 jam sesudah perlakuan diambil kembali darah sebanyak 3 cc dimasukkan tabung vakum plastik yang sudah berisi citrate anticoagulant. Setelah semua data terkumpul, dilakukan analisis deskriptif menurut kelompok perlakuan (HES 40 $\mathrm{kD}$ dan HES $200 \mathrm{kD}$ ). Hasil analisis disajikan dalam bentuk tabel dan grafik. Pembuatan grafik dengan box-plot dilakukan pada gambaran nilai PT dan PTT menurut kelompok perlakuan (HES $40 \mathrm{kD}$ dan HES $200 \mathrm{kD}$ ). Dari hasil uji normalitas data, hasil dengan distribusi normal dilakukan pengujian dengan uji independent t-test. Hasil dengan distribusi tidak normal dilakukan uji non parametrik Mann-Whitney. Semua uji analitik menggunakan $\alpha \leq 0.05$ dengan interval kepercayaan $95 \%$ dan menggunakan software SPSS 11.5.

\section{HASIL}

Penelitian dilakukan pada 46 orang penderita laki-Iaki dan perempuan dengan status fisik ASA I dan II yang memenuhi kriteria inklusi dan eksklusi tertentu, yang dibagi menjadi 2 kelompok, yaitu kelompok A 23 penderita Kelompok HES 40 kD kelompok B 23 orang Kelompok HES $200 \mathrm{kD}$.

Untuk data nominal meliputi jenis kelamin, status ASA dan jenis operasi menggunakan uji Mann Whitney. Untuk data rasio meliputi variabel umur, berat badan, tinggi badan, tekanan darah sistolik, tekanan darah diastolik, tekanan arteri rata-rata, laju jantung, saturasi oksigen, jumlah trombosit, SCOT, SGPT, lama operasi dan jumlah perdarahan selama operasi menggunakan indepedent t-test.

Dari tabel 3 mengenai karakteristik penderita kedua kelompok perlakuan diatas dapat kita lihat bahwa dari uji statistik yang dilakukan menunjukkan perbedaan yang tidak bermakna ( $p$ > 0,05 ) untuk semua variabel yaitu jenis kelamin, status ASA, jenis operasi, umur, berat badan, tinggi badan, tekanan darah sistolik, tekanan darah diastolik, tekanan arteri rata-rata, laju jantung, saturasi 
oksigen, jumlah trombosit, lama operasi dan jumlah perdarahan selama operasi.

Atas dasar hasil uji statistik yang dilakukan pada data dasar subyek penelitian pada kedua kelompok perlakuan dengan hasil menunjukkan perbedaan tidak bermakna, maka kedua keiompok dapat dikatakan homogen dan semuanya layak untuk diperbandingkan
Pada Tabel 4, dinyatakan bahwa tekanan darah sistolik selama pemberian perlakiian tidak terdapat perbedaan secara bermakna dari kedua keiompok ( $\mathrm{p}>$ $0,05)$. Kecuali pada menit ke - 5 terdapat perbedaan yang bermakna. Nilai pada tabel di atas dinyatakan sebagai rerata \pm simpangan baku dengan kisaran.

Tabel 3. Karakteristik Pasien

\begin{tabular}{|c|c|c|c|c|}
\hline $\begin{array}{l}\text { Karakteristik } \\
\text { Pasien }\end{array}$ & $\begin{array}{l}\text { HES 40KD } \\
(n=23)\end{array}$ & $\begin{array}{l}\text { HES 200KD } \\
(n=23)\end{array}$ & Uji Statistik & $\mathrm{P}$ \\
\hline 1.Umur (Tahun) & $41,61 \pm 13,65$ & $43,56 \pm 12,76$ & Indep t-test & 0,618 \\
\hline 2.Jenis Kelamin & & & Mann Whitney & 0,559 \\
\hline Laki-laki & $11(47,82)$ & $13(56,52)$ & & \\
\hline Perempuan & $12(52,18)$ & $10(43,48)$ & & \\
\hline 3.Berat badan $(\mathrm{kg})$ & $56,30 \pm 7,72$ & $57,95 \pm 7,91$ & Indep t-test & 0,477 \\
\hline $\begin{array}{l}\text { 4.Tinggi } \\
\text { badan }(\mathrm{cm})\end{array}$ & $157,26 \pm 3,91$ & $157,78 \pm 3,27$ & Indep t-test & 0,626 \\
\hline 5.Status ASA $(\%)$ & & & Mann Whitney & 0,331 \\
\hline -ASA1 & $18(78,26)$ & $15(65,21)$ & & \\
\hline -ASAII & $5(21,74)$ & $8(34,79)$ & & \\
\hline $\begin{array}{l}\text { 6.Tek. darah } \\
\text { sistolik }(\mathrm{mmHg})\end{array}$ & $127,73 \pm 5,31$ & $127,52 \pm 7,61$ & Indep t-test & 0,911 \\
\hline $\begin{array}{l}\text { 7.Tek. darah } \\
\text { diastolic }(\mathrm{mmHg})\end{array}$ & $7,21 \pm 6,70$ & $76,73 \pm 5,94$ & Indep t-test & 0,709 \\
\hline $\begin{array}{l}\text { 8. Tek. arteri rata- } \\
\text { rata }(\mathrm{mmHg})\end{array}$ & $93,91 \pm 5,98$ & $93,52 \pm 6,14$ & Indep t-test & 0,828 \\
\hline 9. Laju Jantung & $94,13 \pm 8,42$ & $93,04 \pm 8,48$ & Indep t-test & 0,665 \\
\hline 10. Saturasi $\mathrm{O}_{2}$ & $98,67 \pm 1,05$ & $98,58 \pm 1,21$ & Indep t-test & 0,804 \\
\hline 11.Jumlah & $196,42 \pm 14,62$ & $193,89 \pm 15,30$ & Indep t-test & 0,576 \\
\hline Trombosit & & & & \\
\hline 12.SGOT(U/l) & $25,56 \pm 3,86$ & $88,91 \pm 11,17$ & Indep t-test & 0,228 \\
\hline 13.SGPT(U/l) & $49,17 \pm 6,45$ & $26,22 \pm 4,54$ & Indep t-test & 0,604 \\
\hline $\begin{array}{l}\text { 14. Lama operasi } \\
\text { (menit) }\end{array}$ & $15,21 \pm 12,10$ & $50,30 \pm 6,11$ & Indep t-test & 0,553 \\
\hline 15. Jenis Operasi & & & Mann Whitney & 0,769 \\
\hline -Orif & $6(26,1)$ & $9(39,1)$ & & \\
\hline -Excisi Mamae & $6(26,1)$ & $4(17,4)$ & & \\
\hline -Sub Total & $5(21,7)$ & $5(21,7)$ & & \\
\hline Thyroidectomi & & & & \\
\hline -Laparatomi & $6(26,1)$ & $5(21,7)$ & & \\
\hline Eksplorasi & & & & \\
\hline 16. Perdarahan & $651,52 \pm 61,58$ & $676,30 \pm 56,75$ & Indep t-test & 0,163 \\
\hline
\end{tabular}

Keterangan: Uji statistik menggunakan Independent T test dan Mannn Whitney $(\mathrm{p}<0,05)$ 
Tabel 4. Tekanan Darah Sistolik Selama Pemberian Infus Kelompok HES400KD dan Kelompok HES

\begin{tabular}{cccc}
\hline $\begin{array}{c}\text { Tekanan DarahSistolik } \\
\text { Menit ke }\end{array}$ & HES 400KD $(\mathrm{mmHg})$ & HES 200KD $(\mathrm{mmHg})$ & $\mathrm{P}$ \\
\hline 0 & $97,70 \pm 6,35$ & $98,57 \pm 5,61$ & 0,625 \\
5 & $99,00 \pm 3,40$ & $106,60 \pm 7,54$ & 0,001 \\
10 & $109,43 \pm 5,97$ & $110,95 \pm 6,37$ & 0,408 \\
15 & $114,17 \pm 4,17$ & $115,04 \pm 6,76$ & 0,603 \\
20 & $120,65 \pm 5,06$ & $121,04 \pm 3,19$ & 0,756 \\
25 & $125,04 \pm 3,59$ & $126,73 \pm 3,29$ & 0,103 \\
30 & $129,06 \pm 3,46$ & $130,65 \pm 4,14$ & 0,173 \\
35 & $130,36 \pm 3,20$ & $131,47 \pm 3,98$ & 0,599 \\
40 & $132,13 \pm 2,76$ & $132,73 \pm 3,68$ & 0,531 \\
45 & $132,91 \pm 2,37$ & $133,06 \pm 3,48$ & 0,844 \\
\hline
\end{tabular}

Tabel 5. TDD Selama Pemberian Infus Kelompok HES 40kD dan Kelompok HES 200kD

\begin{tabular}{cccc}
\hline $\begin{array}{c}\text { Tekanan DarahSistolik } \\
\text { Menit ke }\end{array}$ & HES 400kD $(\mathrm{mmHg})$ & HES $200 \mathrm{kD}(\mathrm{mmHg})$ & $\mathrm{P}$ \\
\hline 0 & $67,17 \pm 3,73$ & $67,13 \pm 4,22$ & 0,971 \\
5 & $68,17 \pm 3,25$ & $70,95 \pm 3,78$ & $0,008^{*}$ \\
10 & $72,30 \pm 2,28$ & $73,43 \pm 2,29$ & 0,101 \\
15 & $74,47 \pm 2,57$ & $75,65 \pm 0,72$ & 0,076 \\
20 & $74,56 \pm 3,42$ & $76,04 \pm 3,44$ & 0,152 \\
25 & $76,78 \pm 3,04$ & $77,21 \pm 2,69$ & 0,611 \\
30 & $77,73 \pm 2,09$ & $78,04 \pm 2,70$ & 0,672 \\
35 & $77,39 \pm 2,01$ & $77,56 \pm 1,97$ & 0,769 \\
40 & $77,82 \pm 2,14$ & $77,41 \pm 1,12$ & 0,509 \\
45 & $77,39 \pm 2,18$ & $77,08 \pm 1,88$ & 0,616 \\
\hline
\end{tabular}

Keterangan: Uji statistic menggunakan Independent $\mathrm{T}$ tes, dengan derajat kemaknaan $\mathrm{p}<0,05$. $*=$ berbeda makna

Pada Tabel 5, dinyatakan bahwa tekanan darah diastolik selama pemberian perlakuan tidak terdapat perbedaan secara bermakna dari kedua kelompok ( $\mathrm{p}>$ $0,05)$. Kecuali pada menit ke - 5 terdapat perbedaan yang bermakna. Nilai pada tabel di atas dinyatakan sebagai rerata \pm simpangan baku dengan kisaran.
Pada Tabel 6, dinyatakan bahwa tekanan darah arteri rata - rata selama pemberian perlakuan tidak terdapat perbedaan secara bermakna dari kedua keiompok ( $\mathrm{p}>$ $0,05)$. Nilai pada tabel di atas dinyatakan sebagai rerata \pm simpangan baku dengan kisaran.

Tabel 6. Tekanan Arteri rata-rata Selama Pemberian Infus Kelompok HES 40 KD dan Kelompok HES

\begin{tabular}{cccc}
\hline $\begin{array}{c}\text { Tekanan DarahSistolik } \\
\text { Menit ke }\end{array}$ & HES 400KD(mmHg) & HES 200KD(mmHg) & \\
\hline 0 & $78,96 \pm 4,25$ & $78,95 \pm 5,25$ & 0,24 \\
5 & $80,78 \pm 5,06$ & $82,73 \pm 7,08$ & 0,28 \\
10 & $82,60 \pm 4,77$ & $84,82 \pm 5,69$ & 0,15 \\
15 & $85,01 \pm 4,43$ & $86,52 \pm 5,74$ & 0,34 \\
20 & $88,17 \pm 3,48$ & $89,56 \pm 4,19$ & 0,22 \\
25 & $92,30 \pm 2,89$ & $93,21 \pm 2,59$ & 0,26 \\
30 & $93,13 \pm 2,22$ & $93,82 \pm 2,10$ & 0,28 \\
35 & $93,04 \pm 2,22$ & $93,65 \pm 2,10$ & 0,34 \\
40 & $93,60 \pm 1,82$ & $94,00 \pm 1,85$ & 0,47 \\
45 & $93,39 \pm 2,08$ & $93,82 \pm 2,12$ & 0,48 \\
\hline
\end{tabular}

Keterangan : Uji statistic menggunakan Independent $T$ tes, dengan kemaknaa $\mathrm{p}<0,05$ 
Tabel 7. Laju Jantung Selama Pemberian Infus Kelompok HES 40 kD dan Kelompok HES 200kD

\begin{tabular}{cccc}
\hline $\begin{array}{c}\text { Tekanan DarahSistolik } \\
\text { Menit ke }\end{array}$ & HES 400KD $(\mathrm{mmHg})$ & HES $200 \mathrm{KD}(\mathrm{mmHg})$ & $\mathrm{P}$ \\
\hline 0 & $95,91 \pm 7,70$ & $95,35 \pm 7,70$ & 0,805 \\
5 & $94,13 \pm 8,42$ & $93,04 \pm 8,48$ & 0,665 \\
10 & $90,60 \pm 7,86$ & $89,08 \pm 7,56$ & 0,507 \\
15 & $89,47 \pm 5,02$ & $88,04 \pm 5,15$ & 0,344 \\
20 & $87,04 \pm 4,16$ & $86,47 \pm 4,09$ & 0,645 \\
25 & $86,60 \pm 4,09$ & $86,86 \pm 3,87$ & 0,826 \\
30 & $86,60 \pm 4,11$ & $86,65 \pm 3,89$ & 0,855 \\
35 & $87,17 \pm 3,82$ & $87,08 \pm 3,52$ & 0,936 \\
40 & $87,47 \pm 3,72$ & $87,17 \pm 3,47$ & 0,776 \\
45 & $87,21 \pm 3,75$ & $87,00 \pm 3,37$ & 0,837 \\
\hline
\end{tabular}

Keterangan: Uji statistik menggunakan Independent t test, dengan derajat kemaknaan $\mathrm{p}<0,05$

Tabel 8. Perbandingan Rerata Pemeriksaan Koagulasi Preoperasi dan Sesudah 15 menit Pada Kelompk HES

\begin{tabular}{|c|c|c|c|c|c|}
\hline \multirow{3}{*}{ No } & \multicolumn{5}{|c|}{ 40KD dan HES 200KD } \\
\hline & Pemeriksaan & HES 40KD & & Uji Statistik & $\mathrm{P}$ \\
\hline & & $\begin{array}{l}\text { Preoperasi } \\
\quad(n=23)\end{array}$ & $\begin{array}{c}\text { Sesudah 15 } \\
\text { menit }(n=23)\end{array}$ & & \\
\hline 1 & PT & $12,89 \pm 0,91$ & $13,22 \pm 0,84$ & Paired $t$ tes & 0,180 \\
\hline 2 & PTT & $29,72 \pm 1,70$ & $32,69 \pm 0,77$ & $\begin{array}{l}\text { Paired } t \text { tes } \\
\text { HES 200KD }\end{array}$ & $0,013 *$ \\
\hline 3 & PT & $12,85 \pm 0,86$ & $13,31 \pm 0,73$ & Paired $t$ tes & $0,047 *$ \\
\hline 4 & PTT & $29,89 \pm 1,47$ & $34,10 \pm 1,30$ & Paired $t$ tes & $0,000 *$ \\
\hline
\end{tabular}

Keterangan: Uji Statistik menggunakan Paired t test, dengan derajat kemaknaan $\mathrm{p}<0,05$

$*=$ berbeda bermakna

Pada Tabel 7, dinyatakan bahwa laju jantung selama pemberian perlakuan dari tidak terdapat perbedaan secara bermakna dari kedua kelompok ( $p>0,05)$. Nilai pada label di atas dinyatakan sebagai rerata \pm simpangan baku dengan kisaran.

Pada Tabel 8, Nilai dinyatakan sebagai rerata \pm simpangan baku dengan kisaran, pada kelompok HES $40 \mathrm{kD}$ nilai plasma prothrombin time (PT) pada preoperasi dan sesudah 15 menit tidak terjadi perbedaan secara bermakna $(\mathrm{p}=0,180)$, sedangkan partial thromboplastin time (PTT) preoperasi dan sesudah 15 Menit operasi terjadi perbedaan bermakna ( $\mathrm{p}=$ 0,013). Pada kelompok HES 200 KD untuk nilai plasma prothrombin time (PT) dan partial thromboplastin time (PTT) pada preoperasi dan sesudah 15 menit operasi terjadi perbedaan secara bermakna $(p=0,047$ dan $p=0,000)$.

Pada tabel 9, nilai dinyatakan sebagai rerata \pm simpangan baku dengan kisaran, pada kelompok HES $40 \mathrm{kD}$ nilai Plasma Prothrombin Time (PT) pada Sesudah 15 Menit dengan sesudah 4 jam tidak terjadi perbedaan secara bermakna $(\mathrm{p}=0,180)$, sedangkan Partial Thromboplastin Time (PTT) Pada Sesudah 15 Menit dengan 4 jam Operasi terjadi perbedaan bermakna $(\mathrm{p}=0,000)$. Pada kelompok HES $200 \mathrm{kD}$ untuk nilai Plasma Prothrombin Time (PT) dan Partial Thromboplastin Time (PTT) pada Sesudah 15 Menit dan Sesudah 4 Jam terjadi perbedaan secara bermakna $(\mathrm{p}=0,046$ dan $\mathrm{p}=0,000)$ 
Tabel 9. Perbandingan Rerata Pemeriksaan Koagulasi Sesudah 15 menit Dan Sesudah 4 Jam Operasi Kelompok HES 40 KD serta HES 200KD

\begin{tabular}{|c|c|c|c|c|c|}
\hline \multirow[t]{2}{*}{ No } & \multirow{2}{*}{$\begin{array}{l}\text { Pemeriksaan } \\
\text { Koagulasi }\end{array}$} & \multicolumn{2}{|l|}{ HES 40KD } & \multirow[t]{2}{*}{ Uji Statistik } & \multirow[t]{2}{*}{$\mathrm{P}$} \\
\hline & & $\begin{array}{c}\text { Sesudah } 15 \\
\text { menit }(n=23)\end{array}$ & $\begin{array}{l}\text { Sesudah } 4 \text { jam } \\
\quad(n=23)\end{array}$ & & \\
\hline 1 & PT & $13,22 \pm 0,84$ & $13,06 \pm 0,73$ & Paired $t$ tes & 0,180 \\
\hline 2 & PTT & $32,69 \pm 0,77$ & $50,34 \pm 0,92$ & $\begin{array}{l}\text { Paired } t \text { tes } \\
\text { HES 200KD }\end{array}$ & $0,000^{*}$ \\
\hline 3 & PT & $13,38 \pm 0,73$ & $13,06 \pm 0,69$ & Paired $t$ tes & $0,046^{*}$ \\
\hline 4 & PTT & $34,10 \pm 1,30$ & $50,48 \pm 1,58$ & Paired t tes & $0,000^{*}$ \\
\hline
\end{tabular}

Keterangan: Uji Statistik menggunakan Paired t test, dengan derajat kemaknaan $\mathrm{p}<0,05$

$*=$ berbeda bermakna

Tabel 10. Perbandingan Rerata Pemeriksaan Koagulasi Preoperasi Dan Sesudah 4 Jam Operasi Kelompok

\begin{tabular}{|c|c|c|c|c|c|}
\hline \multirow{3}{*}{ No } & \multicolumn{5}{|c|}{ HES $40 \mathrm{kD}$ serta HES $200 \mathrm{kD}$} \\
\hline & Pemeriksaan & HES 40kD & & Uji Statistik & $\mathrm{P}$ \\
\hline & & $\begin{array}{l}\text { Preoperasi } \\
\quad(\mathrm{n}=23)\end{array}$ & $\begin{array}{l}\text { Sesudah } 15 \\
\text { menit }(n=23)\end{array}$ & & \\
\hline 1 & PT & $12,89 \pm 0,91$ & $13,06 \pm 0,73$ & Paired $\mathrm{t}$ tes & 0,491 \\
\hline 2 & PTT & $29,72 \pm 1,70$ & $50,34 \pm 0,92$ & $\begin{array}{l}\text { Paired t tes } \\
\text { HES 200KD }\end{array}$ & 0,143 \\
\hline 3 & PT & $12,85 \pm 0,86$ & $13,06 \pm 0,69$ & Paired $t$ tes & 0,426 \\
\hline 4 & PTT & $29,89 \pm 1,47$ & $50,48 \pm 1,58$ & Paired $\mathrm{t}$ tes & 0,250 \\
\hline
\end{tabular}

Keterangan: Uji Statistik menggunakan Paired t test, dengan derajat kemaknaan $\mathrm{p}<0,05$

*= berbeda bermakna

Pada Tabel 10, Nilai dinyatakan sebagai rerata + simpangan baku dengan kisaran, pada kelompok HES $40 \mathrm{kD}$ nilai plasma prothrombin time (PT) dan partial thromboplastin time (PTT) pada preoperasi dengan sesudah 4 jam operasi tidak terjadi perbedaan secara bermakna ( $\mathrm{p}=0,491$ dan $\mathrm{p}=0,143$ ). Pada kelompok HES $200 \mathrm{kD}$ nilai plasma prothrombin time (PT) dan partial thromboplastin time (PTT) pada preoperasi dengan sesudah 4 jam operasi tidak terjadi perbedaan secara bermakna $(p=0,426$ dan $p=0,250)$

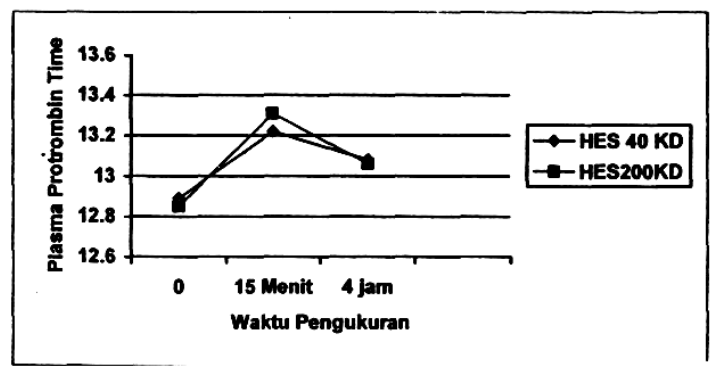

Pada Gambar 6, pada kelompok HES 40 $\mathrm{kD}$ dan $200 \mathrm{kD}$ terdapat pemanjangan Prothrombin Time saat 15 menit setelah perlakuan dan berangsur kembali ke kadar normal setelah 4 jam pemberian.

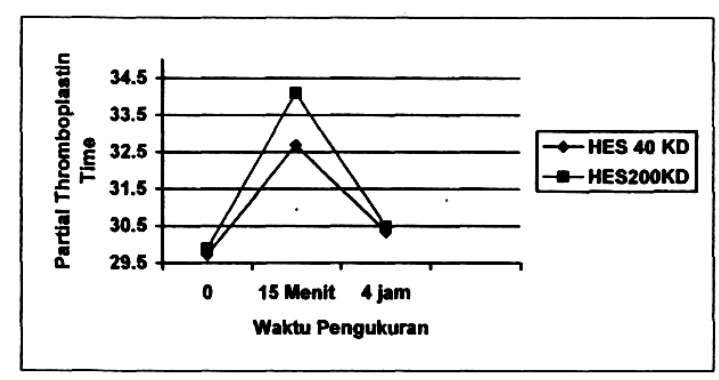

Pada Gambar 7, pada kelompok HES 40 $\mathrm{KD}$ dan $200 \mathrm{kD}$ terdapat pemanjangan Partial Thromboplastin Time saat 15 menit setelah perlakuan dan berangsur kembali ke kadar normal setelah 4 jam pemberian. 
Tabel 11. Perbandingan Rerata Pemeriksaan Koagulasi Preoperasi Kelompok HES 40kD dengan HES 200 $\mathrm{kD}$

\begin{tabular}{|c|c|c|c|c|c|}
\hline \multirow[t]{2}{*}{ No } & \multirow{2}{*}{$\begin{array}{l}\text { Pemeriksaan } \\
\text { Koagulasi }\end{array}$} & \multicolumn{2}{|l|}{ HES 40kD } & \multirow[t]{2}{*}{ Uji Statistik } & \multirow[t]{2}{*}{$\mathrm{P}$} \\
\hline & & $\begin{array}{c}\text { Preoperasi } \\
(\mathrm{n}=23)\end{array}$ & $\begin{array}{c}\text { Sesudah } 15 \\
\text { menit }(n=23)\end{array}$ & & \\
\hline 1 & PT & $12,89 \pm 0,91$ & $12,85 \pm 0,86$ & Paired $t$ tes & 0,895 \\
\hline 2 & PTT & $29,72 \pm 1,70$ & $29,89 \pm 1,47$ & Paired $t$ tes & 0,720 \\
\hline
\end{tabular}

Keterangan: Uji statistik menggunakan independent $t$ test, dengan derajat kemaknaan $\mathrm{p}<0,05$

Tabel 12. Perbandingan Rerata Pemeriksaan Koagulasi Sesudah 15 menit Operasi Kelompok HES 40kD

\begin{tabular}{|c|c|c|c|c|c|}
\hline \multirow[t]{2}{*}{ No } & $\begin{array}{l}\text { Pemeriksaan } \\
\text { Koagulasi }\end{array}$ & $\begin{array}{c}\text { Sesudah } 15 \\
\text { menit }\end{array}$ & & \multirow[t]{2}{*}{ Uji Statistik } & \multirow[t]{2}{*}{$\mathrm{P}$} \\
\hline & & HES 40KD & HES 200KD & & \\
\hline 1 & PT & $13,22 \pm 0,84$ & $13,31 \pm 0,73$ & Paired t tes & 0,710 \\
\hline 2 & PTT & $32,69 \pm 0,77$ & $34,10 \pm 1,30$ & Paired t tes & $0,000 *$ \\
\hline
\end{tabular}

Keterangan: Uji statistic menggunakan Independent $\mathrm{t}$ tes, dengan derajat kemaknaan $\mathrm{p}<0,05$

*= berbeda bermakna

Tabel 13. Perbandingan Rerata Pemeriksaan Koagulasi Sesudah 4 Jam Operasi Kelompok HES 40kD dengan HES 200kD

\begin{tabular}{cccccc}
\hline No & $\begin{array}{l}\text { Pemeriksaan } \\
\text { Koagulasi }\end{array}$ & \multicolumn{2}{c}{ Sesudah 4jam } & Uji Statistik & P \\
\cline { 2 - 4 } & & HES 40KD & HES 200KD & \\
\hline 1 & PT & $13,08 \pm 0,73$ & $13,06 \pm 0,69$ & Paired t tes & 0,918 \\
2 & PTT & $30,68 \pm 0,51$ & $31,06 \pm 0,85$ & Paired t tes & 0,071 \\
\hline
\end{tabular}

Keterangan: Uji statistik menggunakan Independent t test, dengan derajat kemaknaan $\mathrm{p}<0,05$

Pada tabel 11, nilai dinyatakan sebagai rerata \pm simpangan baku dengan kisaran, nilai Plasma Prothrombin Time (PT) pada preoperasi pada kelompok HES $40 \mathrm{kD}$ dengan HES $200 \mathrm{kD}$ tidak terjadi perbedaan secara bermakna $(\mathrm{p}=0,895)$, sedangkan Partial Thromboplastin Time (PTT) pada preoperasi pada kelompok HES $40 \mathrm{kD}$ dengan HES $200 \mathrm{kD}$ tidak terjadi perbedaan secara bermakna $(\mathrm{p}=$ $0,895)$.

Pada tabel 12, nilai dinyatakan sebagai rerata \pm simpangan baku dengan kisaran Nilai Prothrombin Time (PT) sesudah 15 menit operasi pada kelompok HES $40 \mathrm{kD}$ dengan HES $200 \mathrm{kD}$ tidak terjadi perbedaan secara bermakna $(p=0,710)$, sedangkan pada Partial Thromboplastin Time (PTT) sesudah 15 menit operasi pada kelompok HES $40 \mathrm{kD}$ dengan HES
$200 \mathrm{kD}$ terjadi perbedaan secara bermakna $(p=0,000)$. Partial Thromboplastin Time (PTT) pada kelompok HES40 kD nilai rata-ratanya 32,69 sedangkan pada kelompok HES $200 \mathrm{kD}$ lebih panjang dengan rata-rata 34,10 tetapi semuanya masih dalam nilai normalnya.

Pada tabel 13, nilai dinyatakan sebagai rerata \pm simpangan baku dengan kisaran nilai prothrombin time (PT) pada preoperasi operasi pada kelompok HES $40 \mathrm{kD}$ dengan HES $200 \mathrm{kD}$ tidak terjadi perbedaan secara bermakna $(p=0,895)$, sedangkan partial thromboplastin time (PTT) pada preoperasi pada kelompok HES $40 \mathrm{kD}$ dengan HES $200 \mathrm{kD}$ juga tidak terjadi perbedaan secara bermakna $(p=0,071)$. 
Tabel 14. Perbandingan Rerata Pemanjangan Pemeriksaan Koagulasi Sebelum Operasi dan Sesudah 15

\begin{tabular}{ccccc}
\hline \multirow{2}{*}{ No } & $\begin{array}{l}\text { Pemeriksaan } \\
\text { Koagulasi }\end{array}$ & & $\mathrm{P}$ \\
\cline { 3 - 4 } & & HES 40KD & HES 200KD & \\
\hline 1 & PT & $0,40 \pm 1,11$ & $0,46 \pm 1,04$ & 0,863 \\
2 & PTT & $2,97 \pm 1,76$ & $4,21 \pm 1,28$ & $0,009^{*}$ \\
\hline
\end{tabular}

Keterangan: Uji statistik menggunakan Independent $t$ test, dengan derajat kemaknaan $\mathrm{p}<0,05$

Tabel 15. Perbandingan Rerata Pemanjangan Pemeriksaan Koagulasi Sebelum Sesudah 15 Menit dan Sesudah 4 Jam

\begin{tabular}{ccccc}
\hline \multirow{2}{*}{ No } & $\begin{array}{l}\text { Pemeriksaan } \\
\text { Koagulasi }\end{array}$ & \multicolumn{3}{c}{$\mathrm{P}$} \\
\cline { 3 - 4 } & & HES 40kD & HES 200kD & \\
\hline 1 & PT & $0,25 \pm 1,04$ & $0,15 \pm 0,98$ & 0,733 \\
2 & PTT & $2,35 \pm 1,04$ & $3,62 \pm 2,26$ & $0,020^{*}$ \\
\hline
\end{tabular}

Keterangan: Uji statistik menggunakan Independent t test, dengan derajat kemaknaan $\mathrm{p}<0,05$

Tabel 16. Produksi Urin Selama Pemberian HES $40 \mathrm{kD}$ dan $200 \mathrm{kD}$

\begin{tabular}{lclc}
\hline Produksi Urin & \multicolumn{2}{c}{} & $\mathrm{P}$ \\
\cline { 2 - 3 } & HES 40kD & HES 200kD & \\
\hline$>1 \mathrm{cc} / \mathrm{kgBB} / \mathrm{jam}$ & $1,198 \pm 0,118$ & $1,159 \pm 0,090$ & 0,209 \\
$<1 \mathrm{cc} / \mathrm{kgBB} / \mathrm{jam}$ & & & \\
\hline
\end{tabular}

Keterangan: Uji statistik menggunakan Independent t test, dengan derajat kemaknaan $\mathrm{p}<0,05$

Pada tabel 14, nilai dinyatakan sebagai rerata \pm simpangan baku dengan rerata pemanjangan sebelum operasi dan sesudah 15 menit operasi Nilai Prothrombin Time (PT) tidak terjadi perbedaan $\quad \operatorname{bermakna}(p=0,863)$, sedangkan pada Partial Thromboplastin Time (PTT) terdapat perbedaan bermakna dari kedua kelompok $(p=0,009)$.

Pada tabel 15, nilai dinyatakan sebagai rerata \pm simpangan baku dengan kisaran rerata pemanjangan sesudah 15 menit dan sesudah 4 jam operasi selama operasi untuk nilai Prothrombin Time (PT) tidak terjadi perbedaan bermakna $(p=0,733)$ sedangkan pada Partial Thromboplastin Time (PTT) terdapat perbedaan bermakna dari kedua kelompok $(p=0,020)$.

Pada tabel 16, nilai dinyatakan sebagai rerata \pm simpangan baku dengan kisaran jumlah perdarahan selama selama operasi tidak terdapat perbedaan secara bermakna dari kedua kelompok $(p>0,05)$. Produksi urine selama operasi tidak terdapat perbedaan secara bermakna dari kedua kelompok $(p=0,209)$.

\section{PEMBAHASAN}

Penelitian ini membandingkan perbedaan pengaruh pemberian infus HES terhadap Prothrombin Time (PT) dan Partial Thromboplastin Time (PTT). Penderita dibagi menjadi 2 kelompok (kelompok HES 40 kD dan kelompok HES 200 kD) yang masing-masing terdiri dari 23 penderita. Dari data karakteristik penderita, yang meliputi jenis kelamin, status ASA, jenis operasi, umur, berat badan, tinggi badan, tekanan darah sistolik, tekanan darah diastolik, tekanan arteri rata-rata, laju jantung, saturasi oksigen, jumlah trombosit, SGOT, SGPT, lama operasi dan jumlah perdarahan selama operasi, dapat kita lihat tidak didapatkan perbedaan bermakna dari kedua kelompok perlakuan. Variabelvariabel tersebut di atas telah dikendalikan dengan teknik inklusi dan eksklusi. Dengan demikian, kedua kelompok dapat dikatakan homogen dan layak untuk diperbandingkan. 
Hasil pengukuran tanda vital yang meliputi tekanan darah sistolik dan tekanan darah diastolik pada kelompok HES $40 \mathrm{kD}$ terdapat perbedaan yang bermakna pada awal pemberian (menit ke-5). Hal ini sesuai dengan kerja HES sebagai pengisi volume intravaskuler, dimana HES dengan berat molekul yang tinggi akan bekerja lebih cepat dan lebih baik dalam mengisi volume intravaskular. Sedangkan tekanan arteri rerata dan laju jantung pada kedua kelompok relatif stabil dan tidak terdapat perbedaan. Penurunan tekanan darah sistolik dan diastolik, tetapi dengan tekanan arteri rerata dan laju jantung yang stabil, menunjukkan bahwa baik HES $40 \mathrm{kD}$ dan $200 \mathrm{kD}$ mampu mempertahankan kondisi hemodinamik dari pasien. Secara klinis, parameter tekanan arteri rata-rata maupun laju jantung lebih menggambarkan kondisi hemodinamik pasien.

Dari uji statistik, didapatkan bahwa pemberian HES baik kelompok HES 40 $\mathrm{kD}$ dan $200 \mathrm{kD}$ akan menyebabkan memanjangnya waktu PTT setelah diberikan 15 menit. Hal ini sesuai dengan pendapat Kozek-Langenecker SA dan Arellano et al, yang menyatakan bahwa hydroxyethyl starch (HES) menurunkan faktor VIII dan faktor von Willebrand sehingga akan menyebabkan penurunan fungsi platelet. Akibat penurunan faktor VIII, akan terjadi pemanjangan faktor intrinsik pada proses koagulasi yang ditandai dengan pemanjangan kadar PTT, sedangkan pada HES $200 \mathrm{kD}$ terdapat pemanjangan waktu PT. Hal ini sesuai dengan pernyataan Madjpur et al, yang menyatakan bahwa pemberian HES dengan berat molekul tinggi menurunkan fungsi koagulasi baik intrinsik maupun ekstrinsik, sehingga pada pemberian HES $200 \mathrm{kD}$ (berat molekul besar) akan mempengaruhi fungsi koagulasi baik intrinsik (ditandai dengan pemanjanangan waktu PTT) maupun ekstrinsik (ditandai dengan pemanjangan waktu PT). Perlu diperhatikan bahwa, walaupun terdapat pemanjangan waktu dari pemeriksaan PTT (pada kedua kelompok) dan PT (pada kelompok HES 200 kD), pemanjangan waktu ini masih dalam batas harga normal PT yaitu 10-15 detik dan harga normal untuk PTT yaitu 23,435,8 . Tidak didapatkan pula pemanjangan waktu dari kontrol lebih dari 1,5 kali dari normal. Pada pemeriksaan waktu PT dan PTT, antara preoperasi dan 4 jam setelah operasi didapatkan bahwa waktu PTT dan PT pada kedua kelompok kembali ke nilai seperti waktu sebelum operasi. Hal ini menunjukkan bahwa setelah kerja larutan HES berakhir, maka gangguan koagulasi yang timbul akan berangsurangsur kembali ke keadaan sebelum operasi dan bersifat reversibel.

Pada kelompok HES 200 kD di 15 menit setelah pemberian terdapat pemanjangan waktu PTT yang bermakna dibanding dengan kelompok HES $40 \mathrm{kD}$. Hal ini menunjukkan bahwa semakin besar berat molekul HES akan semakin mengganggu fungsi koagulasi. Hal ini sesuai dengan pendapat Standl $\mathrm{T}$ et al dan Holman J yang menyebutkan bahwa berat molekul HES berpengaruh terhadap berat ringannya gangguan koagulasi, dimana semakin kecil berat molekul semakin kecil resiko untuk terjadinya gangguan koagulasi. ${ }^{15,16}$ Pada kedua kelompok tidak terdapat penurunan produksi urin sampai di bawah $1 \mathrm{cc} / \mathrm{kgBB} / \mathrm{jam}$. Hal ini menunjukkan efek samping pemberian HES, baik pada HES $40 \mathrm{KD}$ dan HES $200 \mathrm{KD}$ yaitu penurunan filtrasi ginjal, tidak terjadi bila diberikan sesuai dosis. Ini sesuai pendapat Neff et al yaitu pemberian HES sampai $50 \mathrm{cc} / \mathrm{kgBB}$ tidak menyebabkan gangguan fungsi klirens kreatinin dan aman bagi fungsi ginjal pasien. ${ }^{17}$ 
Hasil penelitian ini belum dapat menjelaskan secara spesifik pengaruh HES pada cascade koagulasi. PT dan PTT sebagai parameter fungsi kogulasi merupakan pemeriksaan tak langsung yang non spesifik terhadap faktor VIII, sebagai faktor yang paling dipengaruhi oleh kerja HES. Meskipun demikian kelainan pada faktor VIII (faktor intrisik) dapat diduga jika kadar PT normal dan kadar PTT memanjang.

\section{SIMPULAN}

Pemberian HES 200 kD memperpanjang nilai Prothrombin Time (PT) dan Partial Thromboplastin Time (PTT) lebih besar daripada HES $40 \mathrm{kD}$. Hal ini dapat menjadi dasar untuk pemakaian HES 40 $\mathrm{kD}$ dan HES $200 \mathrm{kD}$ sebagai alternatif pengganti darah yang aman bila diberikan sesuai dosis, khususnya pada pasien yang dilakukan anestesi umum.

\section{DAFTAR PUSTAKA}

1. Canada Health Ministry. Annual Report 2001-2002. Saskatchewan : Saskatchewan Government; 2002.

2. Hoobs G. Complication During Anesthesia. In ; Aitkenhead AR, Rowbotham DJ, Smith G, eds. Textbook of Anesthsia. $4^{\text {th }}$ Ed. London : Elsevier Science Limited; 2001. P. 501-24.

3. Soenarjo. Resusitasi Cairan. In : Soenarjo, Riwanto I, eds. Penanganan Penderita Gwat Darurat. Semarang : Badan Penerbit Universitas Diponegoro; 2000; p 42-7.

4. Morgan GE. Fluid Management \& Transfusion. In : Morgn GE, Mikhael MS, Murray MJ, eds. Clinical Anesthesiology. $4^{\text {th }}$ Ed. Nem York : Mc Graw Hill Companies; 2006. P 690-707.

5. Prough DS, Wolf SW, Funston S, Svensen $\mathrm{CH}$. Acid Base, Fluids, and Electrolytes. In : Barash PG, Cullen BF, Stoelting RK, eds. Clinical Anesthesia $5^{\text {th }}$ Ed. Philadelphia :Lippincott Williams \& Wilkins; 2006. P 175-207.

6. Stoelting RK, Miller Rdeds. Basics of Anesthesia. $4^{\text {th }}$ Ed. Philadelphia : Churchill Livingstone; 2006. P 233-46.

7. Hall BA, Frigas E, Matesic D, Gillet MD, Sprung J. Case Report. Intraoperative
Anaphylactoid Reaction and Hydroxyethyl Starch in Blanced Electrolyte Solution. Can J Anesthesia. 2006; 53 : p 989-93.

8. Kaye AD, Kucera IJ. Intravascular Fluid and Electrolyte Phisiology. In : Miller RD, ed. Miller's Anesthesia. $6^{\text {th }}$ Ed. Philadelphia : Elsevier Churchill Livingstone; 2005. P 1763-98.

9. Wilkes NJ, Woolf RL, Powanda MC, Gan TJ, Machin SJ, Webb A. Hydroxyethyl Starch in Balanced Electrolyte Solution. Pharmacokinetic and Pharmacodynamic Profiles. Anesth Analg. 2002; 94: p 538-44.

10. Standl T, Burmeister MA, Schroeder F, Currlin E, Schulte J, Freitag M, et al. Hydroxyethyl Starch (HES) 130/0,4 provides Larger and Faster Increases in Tissue Oxygen Tension in Comparison with Prehemodilution Values than HES $70 / 0,5$ or $200 / 0,5$ in Volunteers Undergoing Acute Normovolemic Hemodilution. Anesth Analg. 2003; 96 : 93643.

11. Kozek Langenecker. The Effect of Drugs Used in Anesthesia on Trombosit Membrane Receptors an On Trombosit Function. Medical Chemistry Reviews 2004; 1 : 10110.

12. Sibylie A, Kozek-Langenecker. Effects on Hydroxyethyl Starch Solution on Hemostasis. Anesthesiology $2005 ; 103: 654-60$.

13. Arellano R, Gn BS, Salpeter MJ, Yeo E, McCluskey S, Pinto R et al. A Triple-Blinded Randomized Trial Comparing the Hemostatic Effects of Large-Dose 10\% Hydroxyethyl Starch 264/0,45 versus 5\% Albumin During Major Reconstructive Surgery. Anesth Analg. 2005; $100:$ 1846-53.

14. Madjpour C, Dettori N, Feascolo P, Burki M, Boll M, Fisch A et al. Molecular Weight of Hydroxyethyl Starch : Is There An Effect on Bicod Coagulation and Pharmakokinetics. British Journal Anesthesia. 2005; 10; p 1093201.

15. Neff TA, Doelberg M, Junguheinrich C, Sauerland A, Spahn DR, Stocker R. Repetitive Large Dose Infusion of The Nevel Hydroxyethyl Starch 130/0,4 in Patients with Severe Head Injury. Anesth Analg. 2003; 93 :p 1453-9.

16. Standl T, Burneister MA, Schroeder F, Curline E. Hydroxyethyl Starch (HES) 130/0,4 provides Larger and Faster Increases in Tissue Oxygen Tension in Comparison with Prehemodilution Values than HES $70 / 0,5$ or 200/0,5 in Volunteers Undergoing Acute Normovolemic Hemodilution. Anesth Analg. 2003; 96 : 936-43. 
17. Kostering H, Ghifforn J, NegendankDamenzB. Effect of Expafusin (HES 40/0,5) on The Corpuscular Elements of Blood and Inhibitors of Blood Coagulation. Infusionther Klin Ernahr. 1995; 12 (6) ; p 304-7. 